\title{
Benthic Bacillariophyta of the Paripe River estuary in Pernambuco state, Brazil
}

\author{
Moura, AN. ${ }^{\mathrm{a} *}$, Bittencourt-Oliveira, $M C .^{\mathrm{b}}$ and Nascimento EC. ${ }^{\mathrm{a}}$ \\ ${ }^{a}$ Departamento de Biologia, Universidade Federal Rural de Pernambuco, Recife, PE, Brazil \\ Rua D. Manoel de Medeiros, s/n, Dois Irmãos, CEP 52171-030, Recife, PE, Brazil \\ bDepartamento de Ciências Biológicas, Escola Superior de Agricultura Luiz de Queiroz, \\ Universidade de São Paulo - USP, Piracicaba, SP, Brazil \\ *e-mail: ariadne@db.ufrpe.br
}

Received May 19, 2005 - Accepted March 7, 2006 - Distributed August 31, 2007

(With 36 figures)

\begin{abstract}
The aim of this study was to evaluate the benthic diatom composition from the estuary sediment in the Pernambuco State, based on 32 samples. Samples were collected monthly from September through December 1999 (dry period) and from April through July 2000 (rainy period) during four pre-established sampling stations. Results indicated 19 families and 31 specific and infraspecific taxa. Eight new records were founded for Pernambuco State: Auliscus coelatus, Fallacia nummularia, Navicula algida, Plagiograma pulchellum, Terpsinoe americana, Triceratium antideluvianna and Tryblionella coarctata and one, Auliscus punctatus Bailey, in northeastern Brazil.
\end{abstract}

Keywords: diatom, benthic, estuary.

\section{Bacillariophyta bentônicas do estuário do Rio Paripe, estado de Pernambuco, Brasil}

\begin{abstract}
Resumo
O objetivo do presente estudo foi avaliar a composição das diatomáceas bênticas do sedimento estuarino do estado de Pernambuco, Brasil, com base na análise de 32 amostras. As amostragens foram realizadas mensalmente de setembro a dezembro de 1999 (período seco) e de abril a julho de 2000 (período chuvoso) em quatro estações de coleta previamente estabelecidas. As diatomáceas estiveram representadas por 19 famílias e 31 taxons específicos e infraespecíficos. Ocorreram oito novas citações para o estado de Pernambuco, quais sejam: Auliscus coelatus, Fallacia nummularia, Navicula algida, Plagiograma pulchellum, Terpsinoe americana, Triceratium antideluvianna, Tryblionella coarctata e uma, Auliscus punctatus Bailey, para a região nordeste do Brasil.
\end{abstract}

Palavras-chave: diatomáceas, bentônicas, estuário.

\section{Introduction}

An estuary is a close contact area between a river and the open sea, mixing freshwater from continental drainage and high levels of salinity seawater (Pritchard, 1967). Plant communities living exclusively in contact with the seabed, such as benthic microalgae, are important primary producers in stream runoff, lakes, periodically inundated areas and estuaries. In estuaries these organisms are abundant when the substrate is rich in nutrients.

The mangrove is a very special environment and living in ecosystems like these implies great physiological adaptation, as observed in phanerogams, cryptogams and animals. Such adaptations are explained by great salinity oscillations due to the influence of the mixing of freshwater and seawater regulated by tide variations.

Diatoms are the most representative algae group in estuarine areas, showing wide distribution, mainly as a result of the euryhaline nature of the majority of this taxa, in addition to requiring a more eutrophic environment (Pritchard, 1967).

There are few studies about diatoms in estuaries and mangrove environments in Brazil. Moreira-Filho and Kutners study (1962) stands out for its identification of 66 planktonic, benthic and epiphytic diatoms in estuary areas in Paraná State, as well as including ecological information, such as their distribution in Brazil and the morphometric measurements of the valves. Silva and Cimardi (1989) tested a method that removes the algae from the sediment and listed 22 taxa of diatoms from the estuary of Ratones, in Florianópolis City, Santa Catarina State. Felício-Fernandes and Souza-Mosimann (1994) studied the diatoms from the sediment of the Tavares River estuary in Santa Catarina State, presenting descriptions and illustrations of all algae material. 
In the northeastern region of Brazil there are only studies from Moura et al. (1993) and Azevedo and Cutrim (1999, 2001). Moura et al. (1993) studied the periphytic diatoms on natural and artificial substrata in estuaries of Pernambuco State, showing differences according to the substrate where they were attached. Azevedo and Cutrim (1999) carried out a taxonomic study of the periphytic Naviculales and Bacillarialles of Bostrychia radicans and B. tenera in a mangrove in São Luis Island, in Maranhão State and described 14 species and 2 varieties with illustrations. Azevedo and Cutrim (2001) added 27 infraspecific taxa, with descriptions, illustrations and some ecological data from the same location. Felício-Fernandes et al. (2002) recorded individuals of Nitzschia martiana collected in Santa Catarina and Pernambuco States consisting of benthic/periphytic communities in estuaries, presenting taxonomic information about N. martiana and species of associated diatoms. Cyanobacteria from the bottom of the Paripe River estuary, was studied by Branco et al. (2002).

The existence of only a few studies investigating the benthic microalgae of estuarine areas in Brazil presenting measurements and illustrations stimulates this research that intends to contribute to the knowledge of the benthic diatom composition, thereby increasing floristic information about this group in Brazil.

\section{Material and Methods}

This study was conducted at the Paripe River estuary (Figure 1) in the south of Itamaracá Island, on the north litoral of Pernambuco State ( $7^{\circ} 41^{\prime} 39^{\prime}$ ', $7^{\circ} 48^{\prime} 54^{\prime \prime} \mathrm{S}$ and $34^{\circ} 49^{\prime} 12^{\prime},, 34^{\circ} 53$ ' 13 ' W).

The marine influence is remarkable in throughout almost the whole extension of the estuary, especially during high tides, with the salinity varying between $3.5 \% \mathrm{o}$ and $37.1 \%$ o, with values higher than $20.0 \%$ o near the river-head and oxygen around 4.0 mg.L $\mathrm{L}^{-1}$ (Silva and Koening, 1993).

The tidal flow in the region shows a semi-diurnal pattern, with two low and two high tides in a period of 24 hours.

Samples were collected monthly along the estuarine area from the Paripe River during low tides from
September through December 1999 (dry season) and from April through July 1999 (rainy season), totaling 32.

Four sampling stations were chosen: upstream (Station 1), an intermediate area in the river (Station 2) and two downstream (Stations 3 and 4). Stations 1 and 4 presented sandy sediment and Stations 2 and 3 showed muddy sediment. The sampling of abiotic variables was carried out at one single point just below the surface water in front of Stations 3 and 4 . The $\mathrm{pH}$ was determined using a Beckman potentiometer zeromatic II, the salinity was determined through a Termo Haake refractometer C-10, B-3, the temperature was measured with a mercury thermometer and the dissolved oxygen by the method described by Winkler (1888).

Samples were collected through scraping the surface of the bottom of the estuarine soil, and were fixed with $4 \%$ formaldehyde. All samples collected were rinsed with distilled water using net plankton $(22 \mu \mathrm{m}$ mesh) to wash out the excess sediment. Permanent slides were prepared according to Moreira Filho and Valente Moreira (1981), modified from Simonsen (1974), for a better visualization of the frustule morphology.

The material was analyzed through a Zeiss-Jena light microscope with a coupled photographic apparatus and a micrometer eyepiece. The identification of the species was made using Hustedt (1930, 1955, 1959); Moreno et al. (1996); Silva-Cunha and Eskinazi-Leça (1990) and Round et al. (1990) adopting the classification system from Round et al. (1990).

Considering the presence and absence of the diatoms during the study in the four stations (Table 1), a binary matrix was constructed with the presence signaled by number 1 and absence by number 2 . The similarity matrix was calculated by the Jaccard coefficient (Jaccard, 1901) using NTSYS (NTSYS-PC, 2002) software version 2.1 and the UPGMA algorithm (Sneath and Sokal, 1973) to construct the dendrogram. The numbers shown in Table 1 , based on the dendrogram, represent the species.

All the studied material is deposited in the Professor Vasconcelos Sobrinho Herbarium (PEUFR) of the Universidade Federal Rural de Pernambuco.

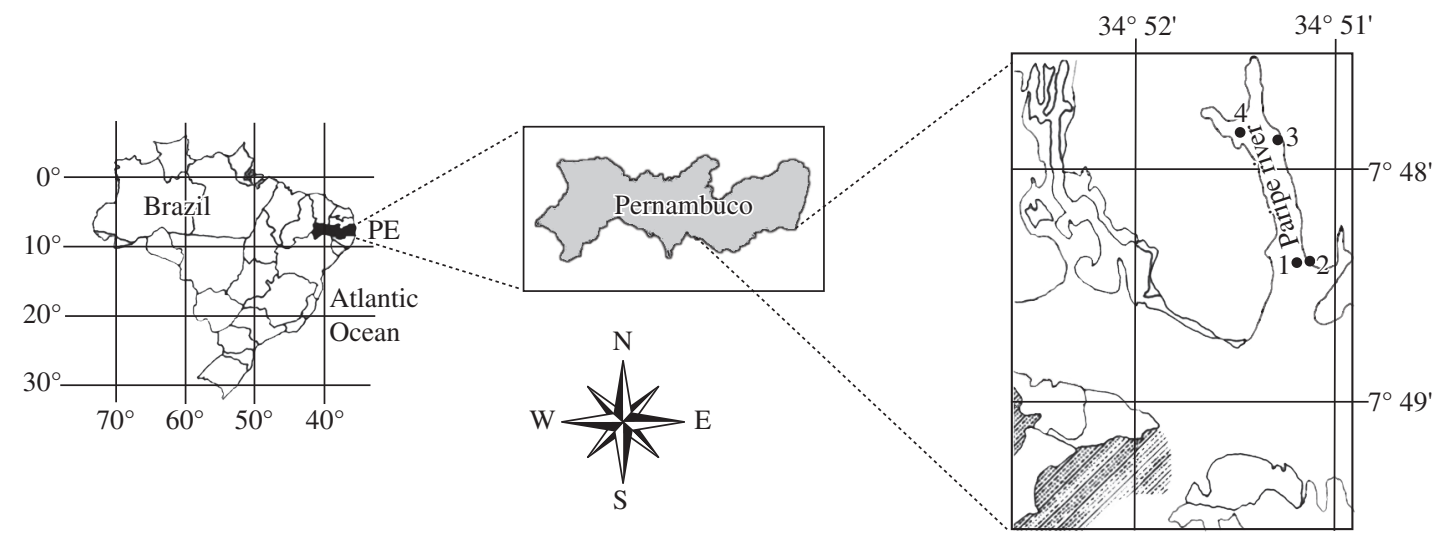

Figure 1. Map showing the localization of sampling stations - Paripe river estuary-Pernambuco-Brazil. 


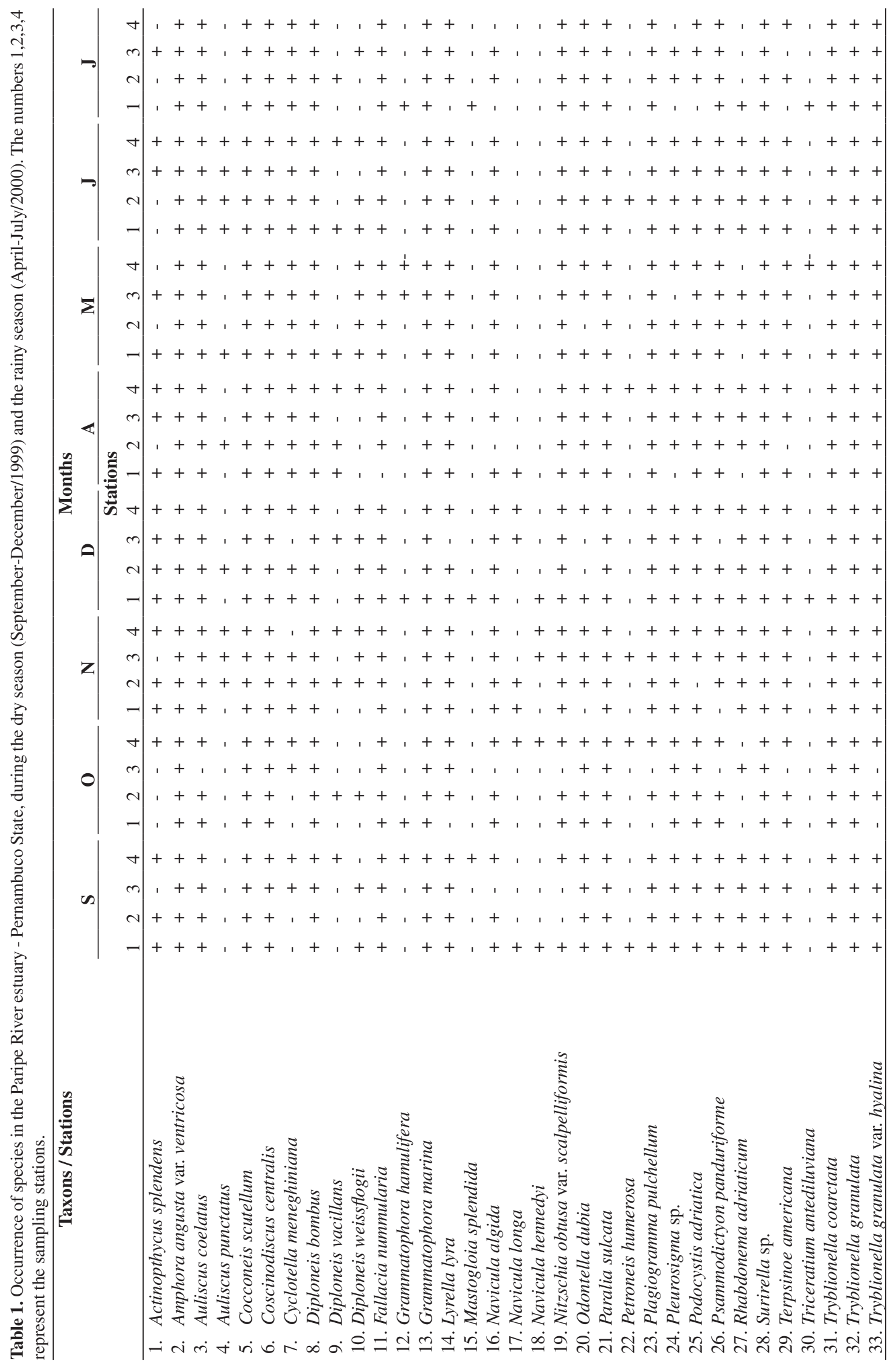




\section{Results}

The occurrence of species in the estuary during the sampling periods is presented in Table 1 . Thirty three species were identified, and distributed in 16 orders and 20 families.

\section{BACILLARIOPHYTA COSCINODISCOPHYCIDAE PARALIALES \\ Paraliaceae}

Paralia sulcata (Ehrenberg) Cleve (Figure 2)

Dimensions: $14.0 \mu \mathrm{m}$ diameter

\section{THALASSIOSIRALES \\ Stephanodiscaceae}

Cyclotella meneghiniana Kützing (Figure 3)

Dimensions: $14.0-19.0 \mu \mathrm{m}$ diameter; $9-10.0$ striae in $10.0 \mu \mathrm{m}$

\section{COSCINODISCALES \\ Coscinodiscaceae}

Coscinodiscus centralis Ehrenberg (Figure 5)

Dimensions: 78.0-94.0 $\mu \mathrm{m}$ diameter; 6-7 areolae in $10.0 \mu \mathrm{m}$

Heliopeltaceae

Actinoptychus splendens (Shadbolt) Ralfs

(Figure 6)

Dimensions: $73.0-77.0 \mu \mathrm{m}$ diameter; 4 areolae in $10.0 \mu \mathrm{m}$

\section{BIDDULPHIOPHYCIDAE BIDDULPHIALES \\ Biddulphiaceae}

\section{Terpsinoe americana (Bailey) Ralfs}

(Figures 19-20)

Dimensions: 47.0-48.0 $\mu \mathrm{m}$ apical axis; 24.5-26.0 $\mu \mathrm{m}$ trans-apical axis (central pseudoseptum); 12 striae in $10.0 \mu \mathrm{m}$.

\section{TRICERATIALES \\ Triceratiaceae}

Auliscus coelatus Bailey (Figure 9)

Dimensions: 54.0-67.0 $\mu \mathrm{m}$ diameter, 2 opposed ocelli.

\section{Auliscus punctatus Bailey (Figure 8)}

Dimensions: 87.0-96.0 $\mu \mathrm{m}$ diameter, oculli with $26.0 \mu \mathrm{m}$.
Odontella dubia (Brightwell) Chávez y Baumgartner (Figure 29)

Dimensions: 29.0-34.0 $\mu \mathrm{m}$ distance wave-angle

Triceratium antidiluviana (Ehrenberg) Grunow (Figure 10)

Dimensions: $40.0-53.0 \mu \mathrm{m}$ of distance between the margins; $53.0-70.0 \mu \mathrm{m}$ of distance between the apices; 6 areolae in $10.0 \mu \mathrm{m}$.

FRAGILARIOPHYCEAE

FRAGILARIOPHYCIDAE

FRAGILARIALES

Fragilariaceae

Podocystis adriatica (Kützing) Ralfs (Figure 34)

Dimensions: 83.8-87.0 $\mu \mathrm{m}$ apical axis; $55.0 \mu \mathrm{m}$ transapical axis (wider area); 3-4 pseudosepto in $10.0 \mu \mathrm{m} ; 15$ striae in $10.0 \mu \mathrm{m}$.

\section{LICMOPHORALES \\ Licmophoraceae}

Plagiogramma pulchellum Greville (Figure 24)

Dimensions: $32.0 \mu \mathrm{m}$ apical axis; $7.5 \mu \mathrm{m}$ transapical axis; 10 striae in $10.0 \mu \mathrm{m}$.

\section{RHABDONEMATALES}

\section{Rhabdonemataceae}

Rhabdonema adriaticum Kützing (Figure 7)

Dimensions: $67.0-70.0 \mu \mathrm{m}$ apical axis; 9-10 striae in $10.0 \mu \mathrm{m}$

\section{STRIATELLALES \\ Striatellaceae}

\section{Grammatophora hamulifera Kützing}

(Figure 27)

Dimensions: $20.0 \mu \mathrm{m}$ apical axis; $16.0 \mu \mathrm{m}$ transapical axis.

\section{Grammatophora marina (Lyngbye) Kützing} (Figure 28)

Dimensions: 29.0-30.0 $\mu \mathrm{m}$ apical axis; $10.0 \mu \mathrm{m}$ transapical axis.

\section{BACILLARIOPHYCEAE}

BACILLARIOPHYCIDAE

\author{
ACHNANTHALES \\ Cocconeidaceae
}




\section{Cocconeis scutellum Ehrenberg (Figure 14)}

Dimensions: $34.0-49.0 \mu \mathrm{m}$ apical axis; $25.0-38.0 \mu \mathrm{m}$ transapical axis; 9 striae in $10.0 \mu \mathrm{m}$.

\section{THALASSIOPHYSALES \\ Catenulaceae}

\section{Amphora angusta Gregory var. ventricosa (Gregory) Cleve (Figure 35)}

Dimensions: 40.0-56.0 $\mu \mathrm{m}$ apical axis; 9.0-10.0 $\mu \mathrm{m}$ transapical axis; 15 striae on the dorsal margin and 16 on the ventral one, in $10.0 \mu \mathrm{m}$.

\section{NAVICULALES \\ Diploneidaceae}

\section{Diploneis bombus Ehrenberg (Figure 21)}

Dimensions: 40.0-43.0 $\mu \mathrm{m}$ apical axis; $20.0-21.0 \mu \mathrm{m}$ transapical axis.

\section{Diploneis vacillans (A. Schmidt) Cleve (Figure 31)}

Dimensions: 22.0-23.0 $\mu \mathrm{m}$ apical axis; $10.5 \mu \mathrm{m}$ transapical axis; $12-13$ striae in $10.0 \mu \mathrm{m}$.

\section{Diploneis weissflogii (A. Schmidt) Cleve} (Figure 26)

Dimensions: $30.0-36.5 \mu \mathrm{m}$ apical axis; $13.0-16.0 \mu \mathrm{m}$ transapical axis (larger segment); 8 striae in $10.0 \mu \mathrm{m}$.

\section{Naviculaceae}

\section{Navicula algida Grunow (Figure 32)}

Dimensions: 50.0-55.0 $\mu \mathrm{m}$ apical axis; $23.0-27.0 \mu \mathrm{m}$ transapical axis; 10 striae in $10.0 \mu \mathrm{m}$.

\section{Navicula hennedyi Wm. Smith (Figure 30)}

Dimensions: 41.5-45.0 $\mu \mathrm{m}$ apical axis; $22.0-24.0 \mu \mathrm{m}$ transapical axis; 11 striae in $10.0 \mu \mathrm{m}$.

\section{Navicula longa Grunow (Figure 33)}

Dimensions: 69.0-73.0 $\mu \mathrm{m}$ apical axis; $12.5-13.5 \mu \mathrm{m}$ transapical axis; 7-8 striae (marginal) in $10.0 \mu \mathrm{m}$.

\section{Pleurosigmataceae}

\section{Pleurosigma sp. (Figure 11)}

Dimensions: $170.0 \mu \mathrm{m}$ apical axis; 21.0-30.0 $\mu \mathrm{m}$ transapical axis; 20 striae in $10.0 \mu \mathrm{m}$.

\section{Sellaphoraceae}

\section{Fallacia nummularia (Greville) D.G. Mann (Figure 4)}

Dimensions: $20.0-25.0 \mu \mathrm{m}$ apical axis; $15.0-19.0 \mu \mathrm{m}$ transapical axis; 12 striae in $10.0 \mu \mathrm{m}$.
LYRELLALES

Lyrellaceae

\section{Lyrella lyra (Ehrenberg) Karayeva (Figure 12)}

Dimensions: 99.0-105.0 $\mu \mathrm{m}$ apical axis; 41.0$43.0 \mu \mathrm{m}$ transapical axis; $8-9$ striae in $10.0 \mu \mathrm{m}$.

\section{Petroneis humerosa (Brébisson) A. J. Stickle} and Mann (Figure 13)

Dimensions: $81.5-88.0 \mu \mathrm{m}$ apical axis; $47.0-50.0 \mu \mathrm{m}$ transapical axis; 9-10 striae in $10.0 \mu \mathrm{m}$.

\section{MASTOGLOIALES \\ Mastogloiaceae}

\section{Mastogloia splendida (Gregory) Cleve (Figure 25)}

Dimensions: $92.0 \mu \mathrm{m}$ apical axis; $75.0 \mu \mathrm{m}$ transapical axis; 5 striae in $10.0 \mu \mathrm{m} ; 4$ chambers in $10.0 \mu \mathrm{m}$.

\section{BACILLARIALES \\ Bacillariaceae}

\section{Nitzschia obtusa Wm. Smith var. scalpelliformis} Grunow (Figure 16)

Dimensions: 68.0-74.0 $\mu \mathrm{m}$ apical axis; 6.5-8.0 $\mu \mathrm{m}$ transapical axis; 9 fibulae in $10.0 \mu \mathrm{m} ; 30$ striae in $10.0 \mu \mathrm{m}$.

\section{Psammodictyon panduriforme (Gregory) D.G. Mann (Figure 17)}

Dimensions: 59.0-68.0 $\mu \mathrm{m}$ apical axis; $23.0-24.0 \mu \mathrm{m}$ transapical axis; 16 transapical striae in $10.0 \mu \mathrm{m}$; 8-9 fibulae in $10 \mu \mathrm{m}$.

\section{Tryblionella coarctata (Grunow) Mann (Figure 18)}

Dimensions: $25.0-30.0 \mu \mathrm{m}$ apical axis; $9.0-10.0 \mu \mathrm{m}$ transapical axis; 14 striae in $10.0 \mu \mathrm{m}$.

\section{Tryblionella granulata (Grunow) Mann (Figure 15)}

Dimensions: $22.0-30.0 \mu \mathrm{m}$ apical axis; $10.0-12.0 \mu \mathrm{m}$ transapical axis; 6-8 striae in $10.0 \mu \mathrm{m} ; 8$ fibulae in $10 \mu \mathrm{m}$.

\section{Tryblionella granulata (Grunow) Mann var. hyalina A. Moss (Figure 22)}

Dimensions: $30.0-37.0 \mu \mathrm{m}$ apical axis; $10.5-15.0 \mu \mathrm{m}$ transapical axis; 6 striae in $10.0 \mu \mathrm{m}$.

\section{SURIRELLALES \\ Surirellaceae}

\section{Surirella sp. (Figure 23)}

Dimensions: 83.0-100.0 $\mu \mathrm{m}$ apical axis; 45.0$58.0 \mu \mathrm{m}$ transapical axis; 2 fibulae in $10.0 \mu \mathrm{m}$; 14 marginal striae and 12 striae in the central area, in $10.0 \mu \mathrm{m}$. 

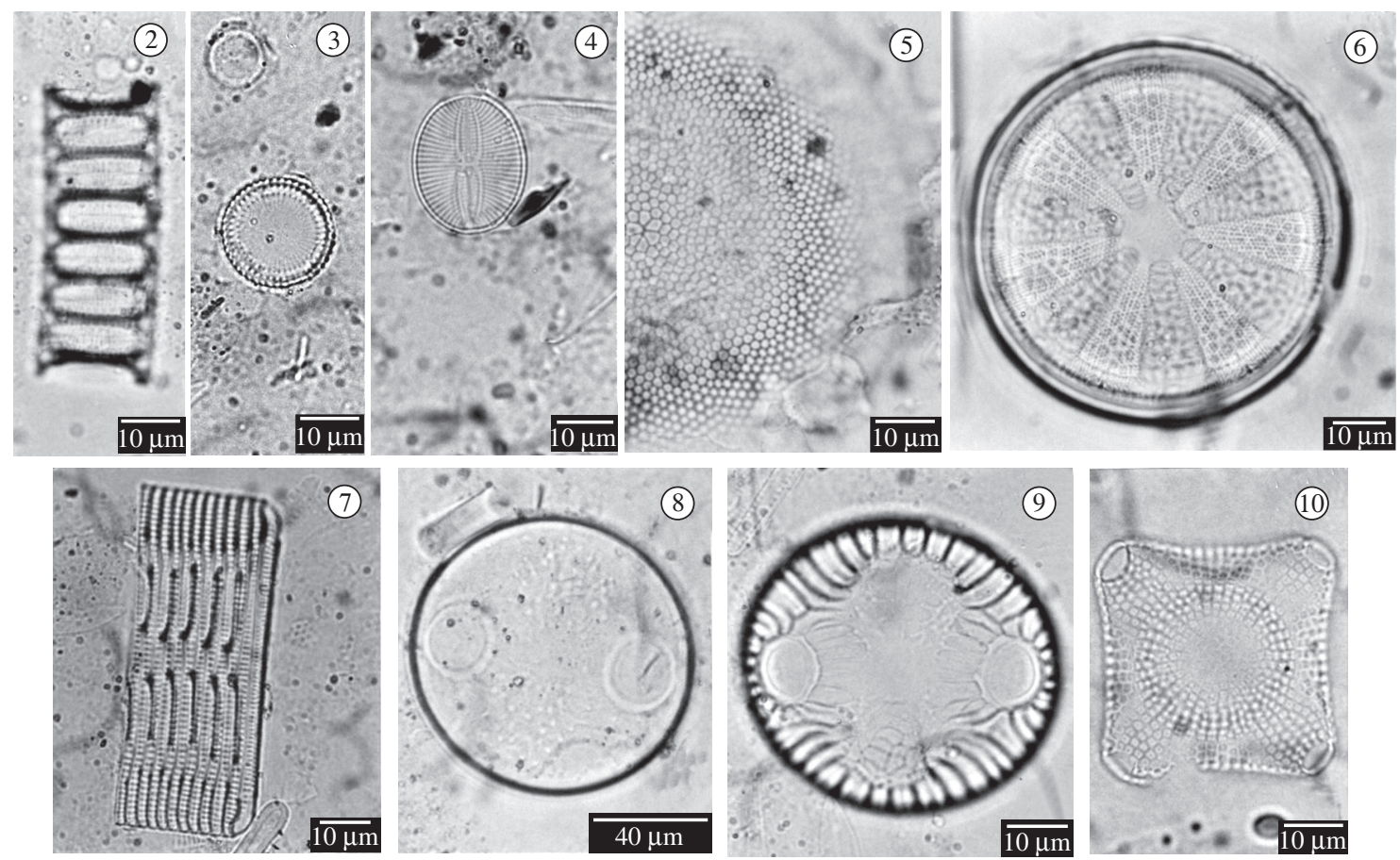

Figures 2-10. 2) Paralia sulcata, 3) Cyclotella meneghiniana, 4) Fallacia nummularia, 5) Coscinodiscus centralis, 6) Actinopthycus splendens, 7) Rhabdonema adriaticum, 8) Auliscus punctatus, 9) Auliscus coelatus, and 10) Triceratium antidiluviana. Scale Bar: 2-7 and 9-10 $=10 \mu \mathrm{m}$ and $8=40 \mu \mathrm{m}$.

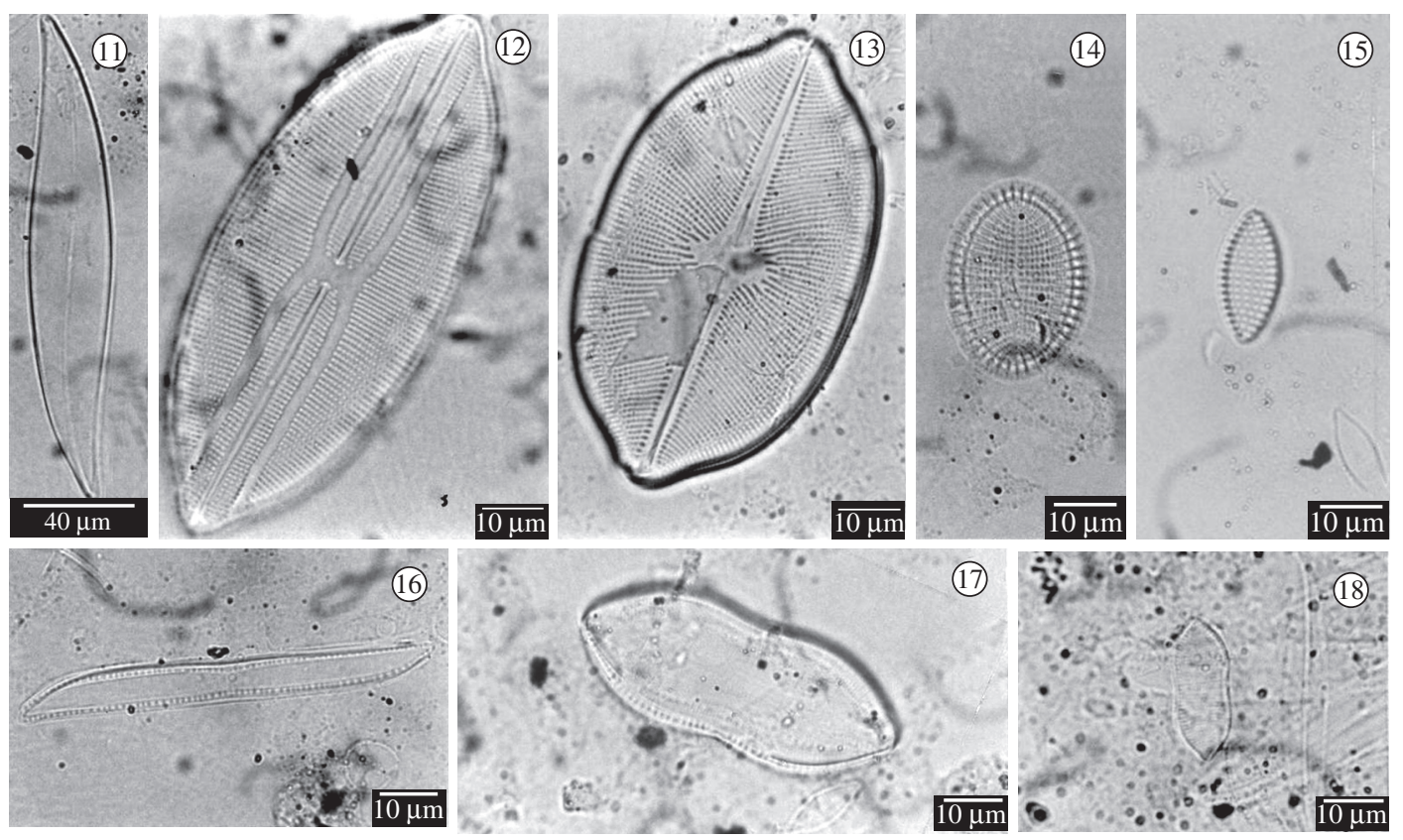

Figures 11-18. 11) Pleurosigma sp., 12) Lyrella lyra, 13) Petroneis humerosa, 14) Cocconeis scutellum, 15) Tryblionella granulata, 16) Nitzschia obtusa var. scalpelliformis, 17) Psammodictyon panduriforme, 18) Tryblionella coarctata. Scale Bar: $11=40 \mu \mathrm{m}$ and $12-18=10 \mu \mathrm{m}$. 

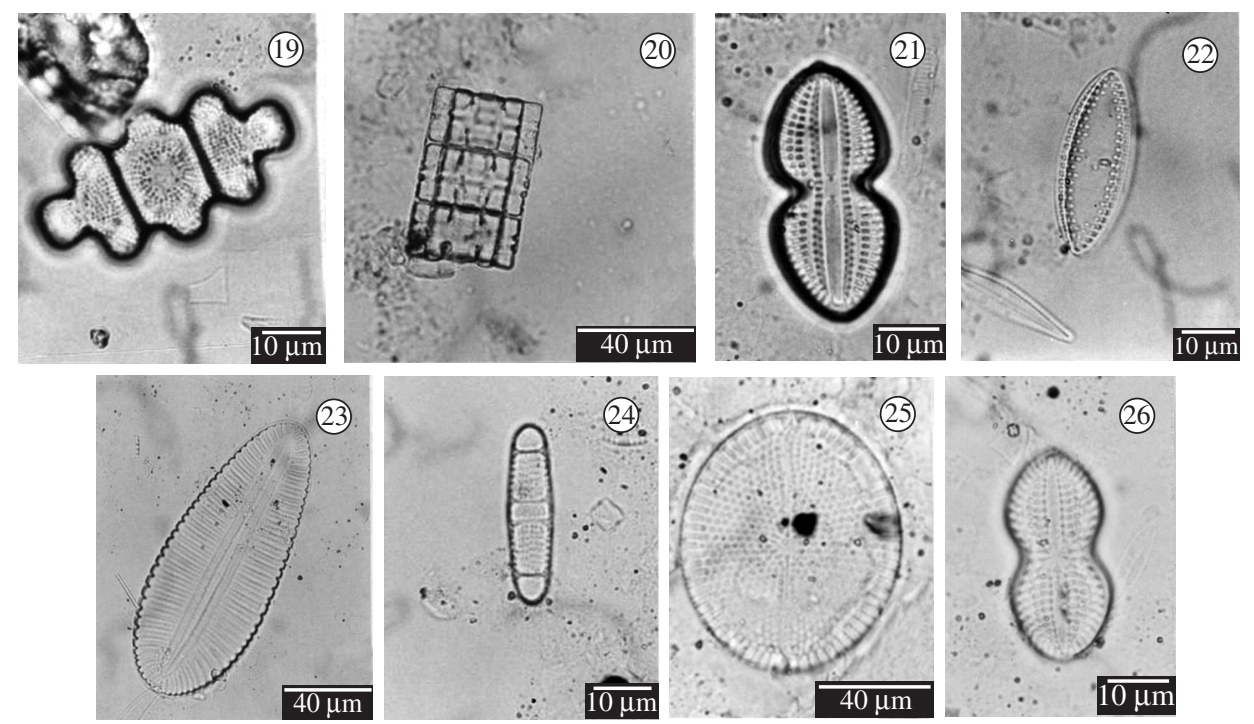

Figures 19-26. 19, 20) Terpsinoe americana, 21) Diploneis bombus, 22) Tryblionella granulata var. hyalina., 23) Surirella sp., 24) Plagiogramma pulchellum, 25) Mastogloia splendida, 26) Diploneis weissflogii. Scale Bar: 20, 23 and $25=40 \mu \mathrm{m}$ and $19,21-22,24,26=10 \mu \mathrm{m}$.
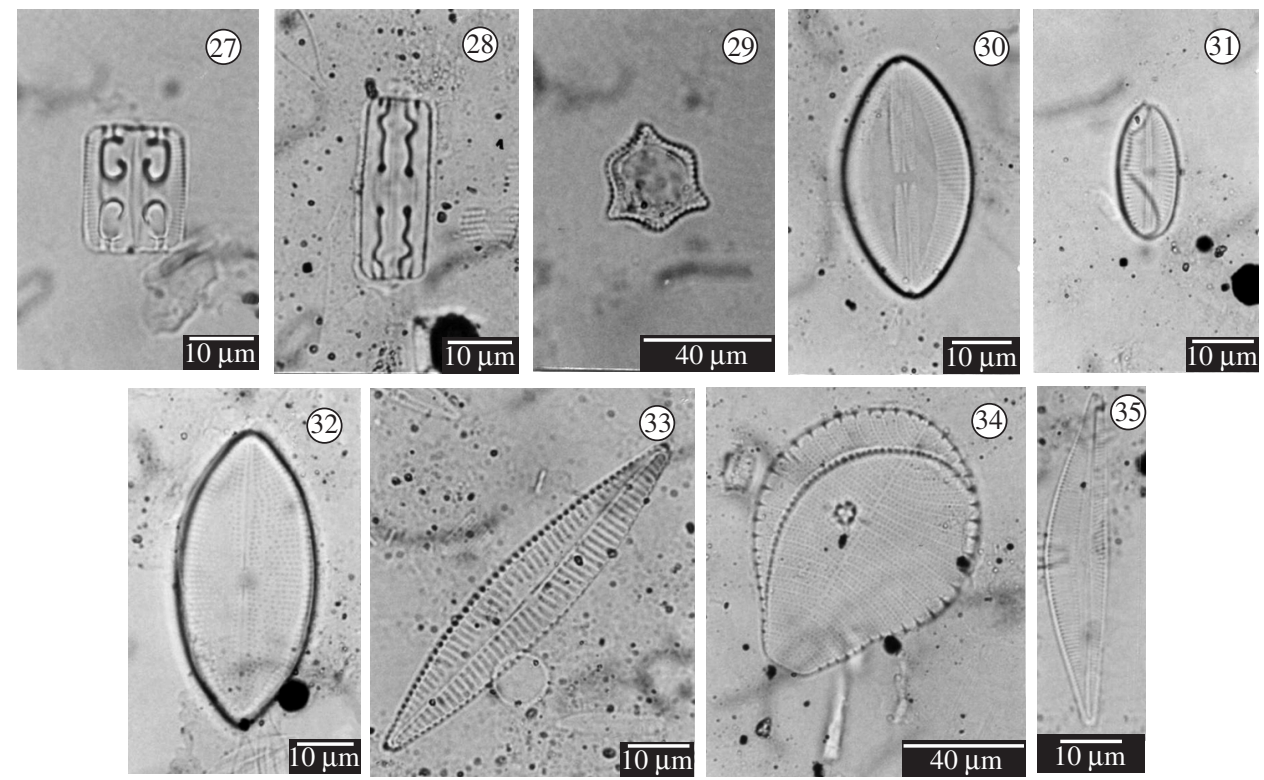

Figures 27-35. 27) Grammatophora hamulifera, 28) Grammatophora marina, 29) Odontella dubia, 30) Navicula hennedyi, 31) Diploneis vacillans, 32) Navicula algida, 33) Navicula longa, 34) Podocystis adriatica, 35) Amphora angusta var. ventricosa. Scale Bar: 27-28,30-33 and $35=10 \mu \mathrm{m}$ and 29 and $34=40 \mu \mathrm{m}$.

The average of the hydrological traits of the estuary analyzed during the period of this study is given in Table 2.

The presence of species (Table 1) during two seasonal periods distinguished three groups of diatoms (Figure 36). Group A was constituted by twenty eight species, grouping most of the taxons identified in the study, which took place in the dry period as much as in the rainy one. Group B was formed of two species (Navicula hennedyi e Petroneis humerosa) and group C included three species (Grammatophora hamulifera, Mastogloia splendida e Triceratium antideluviana) 
The clusters showed a similarity between them $(\mathrm{A}=0.23, \mathrm{~B}=0.37$ and $\mathrm{C}=0.57$ ) (Figure 36$)$, however, in spite of the above mentioned grouping, the similarity values in the constituting of these groups are low.

\section{Discussion}

During the period of this study the temperature was constant throughout the year, $\mathrm{pH}$ was always alkaline, no anoxia was observed even though low oxygen rates and high levels of salinity were determined during the whole period of this study (Table 2). All results corroborated those of Silva and Koening (1993) and Lacerda et al. (1998). From 33 species identified, eight (Auliscus coelatus, Fallacia nummularia, Navicula algida, Plagiograma pulchellum, Terpsinoe americana, Triceratium antidelu- vianna and Tryblionella coarctata) were first mentioned in the State of Pernambuco, and Auliscus punctatus was also first mentioned in northeastern Brazil. This was confirmed after consulting a checklist of marine microalgae of the State of Pernambuco (Eskinazi-Leça et al., 2002). Significant differences in the species composition during the dry and rain seasons were not found (Table 1, Figure 36). The small dimensions of the Paripe River estuary, associated to the elevated influence of the semi-diurnal tidal regime, with two high tides and two low tides in 24 hours, promotes uniform environmental conditions and small variations in salinity which corroborates with the similarity analyses of the species composition.

Benthic diatoms can grow adhered to diverse natural or artificial substrata (Moura et al., 1993; Azevedo

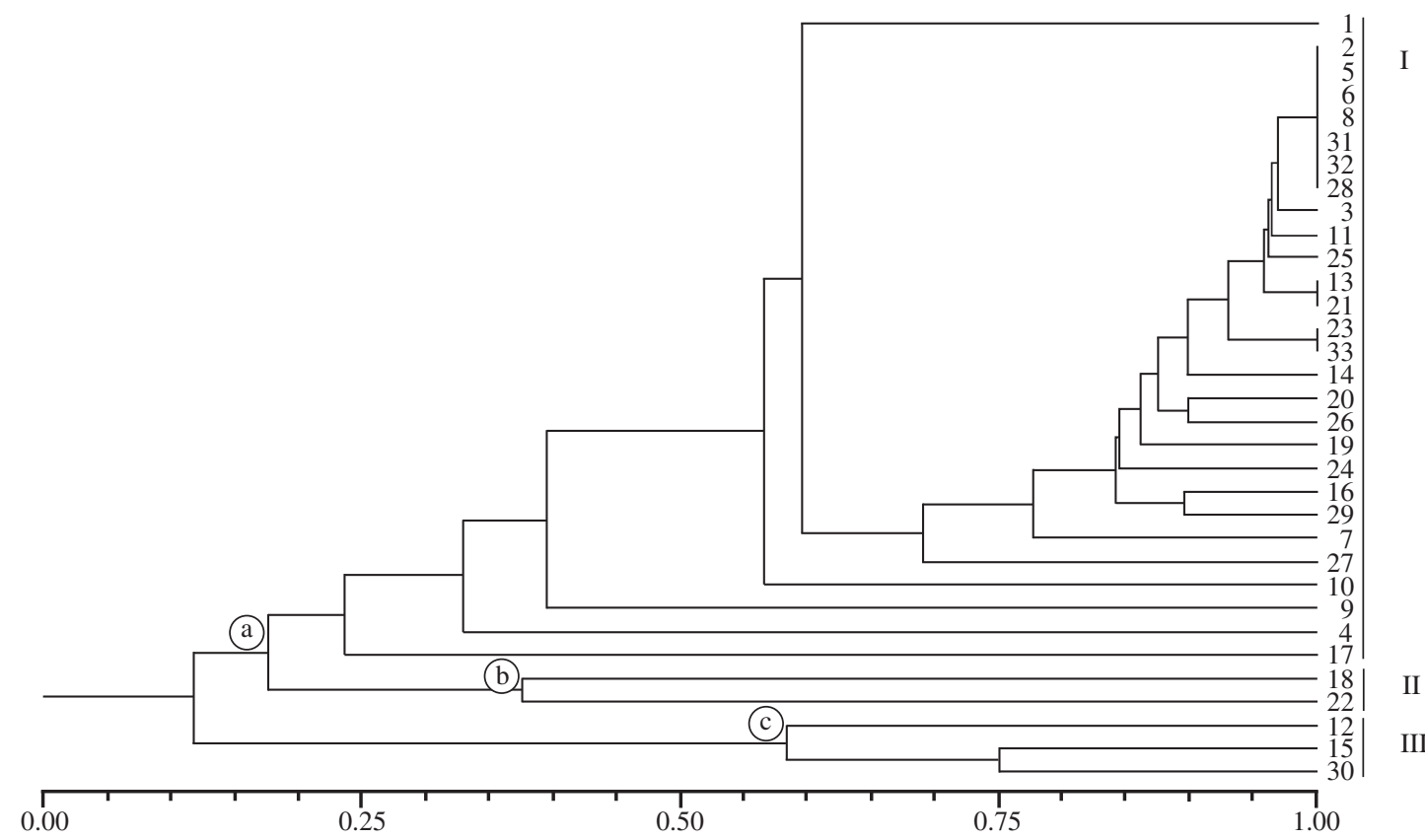

Figure 36. Clustering dendrogram of diatoms by UPGMA analysis of similarity matrix data using 33 OTUs (operational taxonomic units) and Jaccard's coefficient. The numerical scale indicates the level of similarity at which clusters are formed, according to Jaccard's coefficient $(\mathrm{A}=0.23, \mathrm{~B}=0.37$ and $\mathrm{C}=0.57)$.

Table 2. Mean of environmental variables from the four stations during the study in the Paripe River-PE.

\begin{tabular}{lccccc}
\hline Months/Variables & $\begin{array}{c}\text { Water temperature } \\
\left({ }^{\circ} \mathbf{C}\right)\end{array}$ & Salinity & $\mathbf{p H}$ & $\begin{array}{c}\text { Dissolved oxygen } \\
\left(\mathbf{m g . L ^ { - 1 }}\right)\end{array}$ & $\begin{array}{c}\text { Light extinction } \\
\text { coefficient }(\mathbf{m})\end{array}$ \\
\hline April & 35.5 & 29.5 & 7.92 & 1.67 & 1.45 \\
May & 28.5 & 35.0 & 8.16 & 1.82 & 1.50 \\
June & 27.5 & 22.0 & 8.30 & 1.90 & 1.05 \\
July & 30.0 & 25.0 & 8.48 & 2.60 & 0.80 \\
September & 34.0 & 38.0 & 7.92 & 1.82 & 2.76 \\
October & 32.9 & 37.0 & 8.15 & 2.80 & 3.60 \\
November & 32.0 & 36.0 & 8.32 & 2.57 & 2.31 \\
December & 32.5 & 37.0 & 8.48 & 2.60 & 0.80 \\
\hline
\end{tabular}


and Cutrim, 1999, 2001). According to Watherbee et al. (1998), diatoms present a true raphe with a high fixing capacity in many substrata, as a result of excreting mucilaginous substances through the raphe, facilitating the cell adhesion. When it does not possess a raphe or it is only founded in only one valve, adhesion should be possible through extracellular mucilaginous substances excreted by other sites of the frustule (rimoportula), consisting of characteristic fixing structures, such as peduncles and gelatinous masses. Around $76.5 \%$ from the order show raphe and mucilage extrusion strategies (Moura et al., 1993; Felício-Fernandes and Souza-Mosimann, 1994 and Azevedo and Cutrim, 1999, 2000).

We conclude from this analysis that the presence of algae throughout the year, with small remarkable variations, may be a consequence of reduced environmental variations in this ecosystem.

Acknowledgments - This research was supported by the Brazilian Council for Research and Development - CNPq (Proc. 151111/02-2, 302439/2002-1, 470705/2003-5, 302439/2002-1).

\section{References}

AZEVEDO, ACG. DE and CUTRIM, MV., 1999. Diatomáceas epífitas em Bostrychia Montagne (Rhodophyta) do manguezal da Ilha de São Luis, Estado do Maranhão, Brasil: Naviculales e Bacillariales. Boletim Laboratório Hidrobiologia, vol. 12, p.13-22.

-, 2001. Diatomáceas (Bacillariophyta) epífitas em Bostrychia Montagne (Rhodophyta) do manguezal da Ilha de São Luis, Estado do Maranhão, Brasil: excluindo Naviculales e Bacillariales. Boletim Laboratório Hidrobiologia, vol. 13, p. 1-17.

BRANCO, LHZ., MOURA, AN., SILVA, AC. and BITTENCOURT-OLIVEIRA, MC., 2002. Biodiversidade e considerações biogeográficas das cyanobacteria de uma área de manguezal do estado de Pernambuco, Brasil. Acta Botanica Brasilica, vol. 17, no. 4, p. 585-596.

ESKINAZI - LEÇA, E., MOURA, AN., SILVA - CUNHA, M. DA GG. and KOENING, ML., 2002. Microalgas do Estado de Pernambuco. In TABARELLI, M., SILVA, JMC. da (Orgs.) Diagnóstico da Biodiversidade de Pernambuco. Recife: Ed. Massangana, 2002, vol. 2, p. 79-96.

FELÍCIO-FERNANDES, G. and SOUZA-MOSIMANN, RM., 1994. Diatomáceas no sedimento do manguezal de Itacorubi-Florianópolis, Santa Catarina, Brasil. Insula, vol. 23, p. 149-215.

FELÍCIO-FERNANDES, L., ESKINAZI-LEÇA, E., MOURA, AN. and OLIVEIRA, GG., 2002. The occurrence of Nitzschia martiana (AGARDH, CA.) Van Heurck (Nitzschiaceae-Bacillariophyta) in the southwestern Atlantic Ocean. Hoehnea, vol. 29, no. 2, p. 119-131.

HUSTEDT, F., 1930. Die Kieselalgen. Deutschlands, Österreichs und der Schweiz unter Berücksichtigung der übrigen Länder Europas sowie der angrenzenden Meeresgebiete. Leipzig: Akademische Verlagsgesellschaft Geest and Porting K. (L. Rabenhorst, Kryptogamen - Flora von Deustschland, Österreich und der Schweiz, vol.7, no. 1, p. 1-920.

-, 1955. Marine littoral diatoms of Beauforth, North Carolina. Duke Univ. Press, North Caroline, 67p.
-, 1959. Die Kieselalgen. Deutschlands, Österreichs und der Schweiz unter Berücksichtigung der übrigen Länder Europas sowie der angrenzenden meeresgebiete. Leipzig: Akademische Verlagsgesellschaft Geest and Porting K - G.. 920 p. (L. Rabenhorst, Kryptogamen - Flora von Deustschland, Österreich und der Schweiz, vol. 7, p. 2, p. 1-6.

JACCARD, P., 1901. Etude comparative de la distribution florale dans une portion des Alpes et du Jura. Bulletin Soc. Vaud. Sc. Nat. vol. 37, p. 547-579.

LACERDA, SR., ESKINAZI-LEÇA, E. and KOENING, ML., 1998. Composição e variação da flora das diatomáceas no estuário do rio Paripe (Itamaracá-Pernambuco-Brasil). Trabalhos Oceanográficos da Universidade Federal de Pernambuco, vol. 26, no. 2, p. 19-30.

MOREIRA FILHO, H. and KUTNER, MB., 1962. Contribuição ao conhecimento das diatomáceas do manguezal de Alexandra (Baía de Paranaguá-Paraná-Brasil). Boletim da Universidade do Paraná (Botânica), vol. 4, no. 1, p. 1-30.

MOREIRA-FILHO, H. and VALENTE MOREIRA, IM., 1981. Avaliação taxonômica e ecológica das diatomáceas (Bacillariophyceae) epífitas em algas pluricelulares obtidas nos litorais dos estados do Paraná, Santa Catarina e São Paulo. Boletim Museu Botânico Municipal, vol. 47, no. 1, p. 1-17.

MORENO, JN., LICEA, S. and SANTOYO, H., 1996. Diatomeas del Golfo de California. $1^{\text {a }}$ edição. Universidad Autonoma de Baja California Sur, Baja California Sur, 274p.

MOURA, AN., PASSAVANTE, JZO., SILVA-CUNHA, MGG. and ESKINAZI-LEÇA, E. 1993. Diatomáceas perifíticas fixadas em substratos natural e artificial nos estuários dos Rios Paripe e Igarassu-Ilha de Itamaracá-PE. Trabalhos Oceanográficos da Universidade Federal de Pernambuco, vol. 22, p. 83-96.

PRITCHARD, DN., 1967. What is an estuary: Physical view point. In Lauff, GH., ed. Estuaries. Washington., Am. Ass. Adv. Sci., p. 3-5.

ROUND, FE., CRAWFORD, RM. and MANN, DGT., 1990. The diatoms: Biology \& Morphology of the Genera. Cambridge University Press., 747p.

SILVA, RL. and CIMARDI, JM., 1989. Nota sobre a utilização do "Trapping method" no estudo das diatomáceas epipélicas do manguezal de Ratones - Florianópolis - SC. Insula, vol. 19, (Supp.), p. 299-304.

SILVA, IG. and KOENING, ML., 1993. Variação sazonal da densidade fitoplanctônica no estuário do Rio Paripe (Itamaracá-PE). Arquivos Biologia e Tecnologia, vol. 36, no. 4, p. 645-658.

SILVA-CUNHA, MG., ESKINAZI-LEÇA, E. and ALMEIDA, CDP., 1990. Estrutura e distribuição do microfitoplâncton na região compreendida entre o Amapá e a Paraíba (Operação Norte - Nordeste). Anais IV Enc. Bras. Plâncton, p. 9-38.

SIMONSEN, R. 1974. The diatom plankton of Indian Ocean Expedition of R.V. "Meteor" 1964-1965. Meteor. Forsch., Reih. D., vol. 19, p. 1-66, 41pls.

SNEATH, PHA. and SOKAL, RR., 1973. Numerical taxonomy. San Francisco: W.H. Freeman, 635p.

WATHERBEE, R., LIND, LJ., BURKE, J. and QUATRANO, SR., 1998. The first kiss: establishment and control of initial adhesion by raphid diatoms. Journal of Phycology, vol. 34, no. 1, p. 9-15.

WINKLER, LW., 1888. Die Bestimmung des in Wasser Gelosten Sauerstoffs. Ber. Dtsch.Chem.Ges., vol. 21, 2843-54. 
